generous $\mathrm{R} \& \mathrm{D}$ grants, which helped accelerate high-tech R\&D. "Biotech, however, has been traditionally underserved," says Mordecai Soloff, managing partner, US-Israel business group at Price Waterhouse (New York). The policy of the last chief scientist, Shuki Gleitman, who allocated only $4 \%$ of his budget to biotechnology and $80 \%$ to electronics, was typical.

"Biotechnology has been considered a more risky investment by Israeli venture capitalists and by those setting up shop here," says Yuval Binur, a partner at Medica (Tel Aviv, Israel), a dedicated medical VC fund. Although the number of biotechnology startups tripled between 1988-1992, the commercial success rate did not keep paceperhaps because of a lack of funding, which Yozma has made strides to remedy. Of about 80 biotechnology companies in Israel, about 30 have been started since 1995 . These have a greater chance of surviving because they have received funding following the first round, says Shirley Kutner, who served as senior advisor in the Office of the Chief Scientist from 1991 -1996 . And, of $\$ 250$ million in biotechnology product sales in Israel last year, most was in agricultural biotechnology and dia-

gnostics, with medical instrumentation and drug development lagging because of funding, not brainpower, Kutner says.

Since the establishment of Yozma, venture capital available to Israel has grown to between $\$ 800$ million and $\$ 1.5$ billion, with over 40 active venture capital funds, says David Rubin, economic minister at the Israeli consulate in New York. About $40 \%$ of the capital has come from outside Israel: $56 \%$ from the US, 33\% from Europe, and $11 \%$ from Asia.

Vicki Brower

\title{
Environmental genome project planned
}

An ambitious new project to resequence genes implicated in environmental carcinogenesis is being planned by the US National Institute of Environmental Health Sciences (NIEHS, Research Triangle Park, NC). The Environmental Genome Project (EGP) will attempt to build "the capacity for correlating individual genetic differences with exposure outcomes so that exposure-disease relationships can be more precisely addressed," says Sam Wilson, deputy director of NIEHS.

Roughly 1,000 people from several different geographic and racial populations are expected to provide DNA samples for resequencing of more than 200 genes to create a database of sequence variation. NIEHS researcher Douglas Bell adds, "the specific goal is to discover new functional polymorphisms in genes that are relevant to environmental health." The genes, which will be selected by an NIEHS-moderated peer-review process, are putatively important in environmental carcinogenesis, including genes in metabolic pathways, DNA repair genes and genetic targets for cell cycling, apoptosis, immune and inflammatory response, nutritional and oxidative processes, and signal transduction. Given that many of these genes are also important in drug metabolism and response, the EGP will no doubt be intently monitored by the pharmaceutical industry.
NIEHS is looking for as broad an input as possible from other investigators, trying to "include stakeholders in the discussion," says Wilson. To that end, the administrators have posted a description of the project, along with a candidate gene submission form on the Internet, at http://www.niehs.nih.gov/dirosd/policy/egp. They especially request nominations for potential target genes to supplement the extensive list of metabolic and DNA repair genes long implicated in environmental carcinogenesis.

Published reports have estimated the pricetag of the project at $\$ 60$ million, but Wilson is quick to point out that those costs will be shared by several agencies at NIH. NIH director Harold Varmus agrees that "[o]bviously, the proposed Environmental Genome Initiative is of great interest to NCI [the National Cancer Institute] and NHGRI [ the National Human Genome Research Institute], in addition to the instigator, NIEHS, and there is considerable interaction among these institutes (and others) in planning and funding the effort."

NIEHS is sponsoring a symposium to discuss the EGP on October 17-18, 1997 at $\mathrm{NIH}$ in Bethesda, Maryland. Interested researchers can find registration information on the EGP website.

Chris Dickey

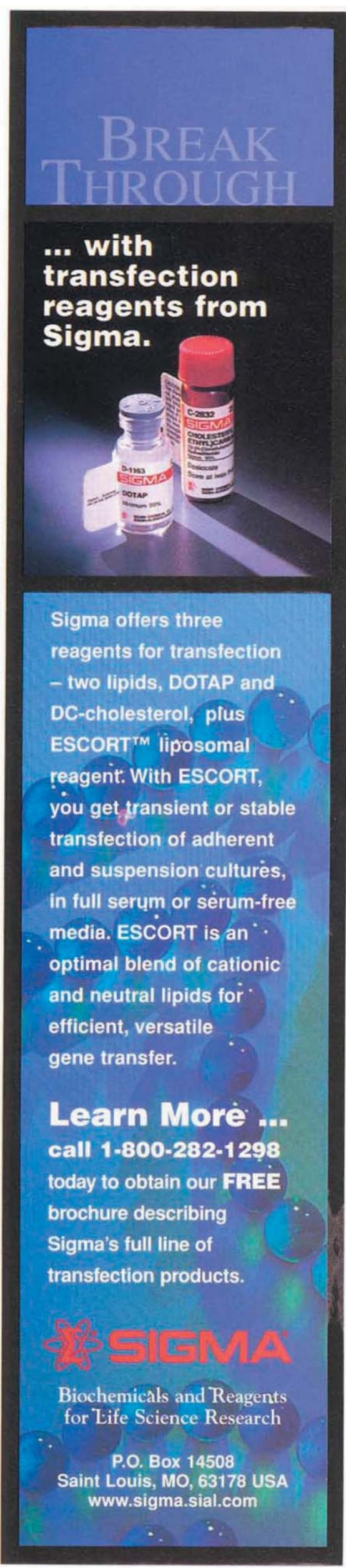

